\title{
Novel 2-mercaptobenzimidazole derivatives: synthesis and evaluation of their antibacterial and antioxidant activities
}

\author{
Latifa El Ouasif ${ }^{1}$, Abdelhakim Bouyahya ${ }^{2}$, Rachid Zniber**, Mostafa El Ghoul 1,*, Redouane Achour ${ }^{\text {, }}$ \\ Hind Chakchak $^{3}$, Ahmed Talbaoui ${ }^{2}$, Houria El Boury ${ }^{2}$, Nadia Dakka ${ }^{2}$ and Youssef Bakri ${ }^{2}$ \\ ${ }^{1}$ Laboratory of Organic Heterocyclic Chemistry, (URAC 21) Pole of Competence Pharmacochemistry, \\ Mohammed V University, Faculty of Science, Ibn Battuta Avenue BP 1014 RP, Rabat, Morocco \\ ${ }^{2}$ Biochemistry-Immunology Laboratory, Mohammed V University, Faculty of Science, Ibn Battuta Avenue BP \\ 1014 RP, Rabat, Morocco \\ ${ }^{3}$ National Centre for Scientific and Technical Research (CNRST), Rabat, Morocco
}

\begin{abstract}
In the present study, a series of novel 2-mercaptobenzimidazolium were synthesized. These compounds can be prepared by condensation of 2-mercaptobenzimidazole with the various alkylating agents under the conditions of phase transfer catalysis, followed by a quaternization. The newly synthesized compounds were subjected to in vitro biological evaluation. The antibacterial activity was evaluated with diffusion assay and optical density method. The antioxidant activity was carried out using DPPH free radical scavenging assay. The result indicated that some compounds show convincing antibacterial activities against two microorganisms: Escherichia coli and Staphylococcus aureus. While these molecules have not shown any interesting antioxidant effects.
\end{abstract}

Keywords: 2-mercaptobenzimidazole, 2-mercaptobenzimidazolium, Antibacterial activity, Antioxidant activity.

\section{Introduction}

The benzimidazole ring is an important pharmacophore in modern drug discovery. The compounds bearing benzimidazole moiety are reported to possess a number of interesting biological activities. Its derivatives and particularly 2-mercaptobenzimidazoles were evidenced promising biological efficacies enabling them to perform as new drug. Exceptional structural features of this class of heterocycle and versatile biological applications made it a privileged structural backbone in new drug design and discovery.

The compounds derived from 2-mercaptobenzimidazole have attracted the attention of several researchers for their properties which exhibit significant biological and pharmacological activities such as antibacterial, antioxidant ${ }^{1-3}$, anticonvulsant ${ }^{4}$, antimicrobial ${ }^{5}$ antihistaminic ${ }^{6}$ nootropic ${ }^{7}$, anti-tubercular ${ }^{8}$ and analgesic ${ }^{9}$ activities. Although, a great interest of the scientific literature concerning 2-mercaptobenzimidazole is in the area of medicinal chemistry, 2-mercaptobenzimidazole is also used in non-biological applications, it serves as plant growth regulators ${ }^{10}$, as natural rubber ${ }^{11}$ and used as corrosion inhibitor for mild steel ${ }^{12-16}$.

Nowadays, a large number of benzimidazole derivatives used as surfactants have been reported in various researches ${ }^{17-24}$. Indeed, the benzimidazolium with long-chain constitute a very interesting family of cationic amphiphiles whose structure and nature of against ion can easily be modulated. This makes them of special interest for biological and especially biomedical applications. Consequently, great effort has been made to develop efficient methods for the preparation of new compounds may present interesting surfactant properties, thus it was of value to synthesize some new benzimidazolium derivates of 2-mercaptobenzimidazole and evaluate their antibacterial and antioxidant activity.

\section{Results and Discussion}

\section{Synthesis}

We report here our results on the synthesis of 2mercaptobenzimidazolium using a two-step procedure as shown in (Scheme 1) and (Scheme 2). First, we investigated the reaction conditions for the synthesis of 2-mercapto-benzimidazole N,S-disubstituted. The 
reaction of 2-mercaptobenzimidazole with n-alkyl bromides reagent using $\mathrm{K}_{2} \mathrm{CO}_{3}$ as base in N,N-Dimethylformamide as solvent at room temperature for $24 \mathrm{~h}$ to provide N,S-disubstituted 2mercaptobenzimidazoles 3a-d in good yields (Table 1).
In continuation of our studies, we then focused to convert these compounds corresponding salts in a quaternization type reaction. As expected, reaction of compounds2-mercapto-benzimidazole N,S-disubstituted 3a-d with n-alkyl bromides in acetonitrile as solvent under reflux for $72 \mathrm{~h}$ furnished the compounds 4a-d in good yields (Table 2).<smiles>[R]Sc1nc2ccccc2n1[R]</smiles>

$$
\begin{aligned}
& \mathrm{a}: \mathrm{R}=-\mathrm{CH}_{2}\left(\mathrm{CH}_{2}\right)_{6} \mathrm{CH}_{3} \\
& \mathbf{b}: \mathrm{R}=-\mathrm{CH}_{2}\left(\mathrm{CH}_{2}\right)_{7} \mathrm{CH}_{3} \\
& \mathrm{c}: \mathrm{R}=-\mathrm{CH}_{2}\left(\mathrm{CH}_{2}\right)_{8} \mathrm{CH}_{3} \\
& \text { d }: \mathrm{R}=-\mathrm{CH}_{2}\left(\mathrm{CH}_{2}\right)_{10} \mathrm{CH}_{3}
\end{aligned}
$$

Scheme 1 1-alkyl-2-(alkylthio)-1H-benzimidazoles 3a-d

Table 1. 1-alkyl-2-(alkylthio)- $1 H$-benzimidazoles 3a-d yields.

\begin{tabular}{|c|c|c|}
\hline Entry & $\mathbf{R}$ & Yield \% \\
\hline 3a & $-\mathrm{CH}_{2}\left(\mathrm{CH}_{2}\right)_{6} \mathrm{CH}_{3}$ & 88 \\
\hline 3b & $-\mathrm{CH}_{2}\left(\mathrm{CH}_{2}\right)_{7} \mathrm{CH}_{3}$ & 91 \\
\hline 3c & $-\mathrm{CH}_{2}\left(\mathrm{CH}_{2}\right)_{8} \mathrm{CH}_{3}$ & 93 \\
\hline 3d & $-\mathrm{CH}_{2}\left(\mathrm{CH}_{2}\right)_{10} \mathrm{CH}_{3}$ & 93 \\
\hline
\end{tabular}<smiles>[R][R]Sc1nc2ccccc2n1[R]</smiles>

$$
\begin{aligned}
& \mathrm{a}: \mathrm{R}=-\mathrm{CH}_{2}\left(\mathrm{CH}_{2}\right)_{6} \mathrm{CH}_{3} \\
& b: \mathrm{R}=-\mathrm{CH}_{2}\left(\mathrm{CH}_{2}\right)_{7} \mathrm{CH}_{3} \\
& \mathrm{c}: \mathrm{R}=-\mathrm{CH}_{2}\left(\mathrm{CH}_{2}\right)_{8} \mathrm{CH}_{3} \\
& \text { d }: \mathrm{R}=-\mathrm{CH}_{2}\left(\mathrm{CH}_{2}\right)_{10} \mathrm{CH}_{3}
\end{aligned}
$$

Scheme 2. Synthesis of 1,3-dialkyl-2-(alkylthio)- $1 H$-benzimidazolium bromides 4a-d 
Table 2. Yields of 1,3-dialkyl-2-(alkylthio)- $1 H$-benzimidazolium bromides 4a-d.

\begin{tabular}{|c|c|c|}
\hline Entry & $\mathbf{R}$ & Yield \% \\
\hline 4a & & 88 \\
\hline 4b & $-\mathrm{CH}_{2}\left(\mathrm{CH}_{2}\right)_{6} \mathrm{CH}_{3}$ & 80 \\
\hline $\mathbf{4 c}$ & $-\mathrm{CH}_{2}\left(\mathrm{CH}_{2}\right)_{7} \mathrm{CH}_{3}$ & 83 \\
\hline $\mathbf{4 d}$ & $-\mathrm{CH}_{2}\left(\mathrm{CH}_{2}\right)_{8} \mathrm{CH}_{3}$ & 78 \\
\hline
\end{tabular}

The structure of the obtained compounds $\mathbf{3 a}-\mathbf{d}$ and 4a-d was confirmed by the NMR and MS spectra. The proton spectrum ${ }^{1} \mathrm{H}-\mathrm{NMR}$ of $\mathbf{4 a}$ in $\mathrm{CDCl}_{3}$ showed a multiplet between $7.18 \mathrm{ppm}$ and $7.26 \mathrm{ppm}$ for the aromatic protons, a triplet at 4.29 ppm for $\mathrm{NCH}_{2}$ and a triplet at 3.38 ppm for $\mathrm{SCH}_{2}$, a multiplet between $1.24 \mathrm{ppm}$ and $1.86 \mathrm{ppm}$ corresponding to the protons of methylene groups of the hydrocarbon chain and a triplet at $0.85 \mathrm{ppm}$ for $\mathrm{CH}_{3}$. On the other hand, the ${ }^{13} \mathrm{C}-\mathrm{NMR}$ spectrum of 4a in $\mathrm{CDCl}_{3}$ shows a signal at $169.0 \mathrm{ppm}$ for the carbon bonded to the sulphur atom and other signals between $32.8 \mathrm{ppm}$ and $22.6 \mathrm{ppm}$ corresponding to the methylene groups then a signal at $14.0 \mathrm{ppm}$ for $\mathrm{CH}_{3}$. The mass spectra were in accord with the structures of the obtained compounds.

\section{Antibacterial activity}

The results of the antimicrobial activity of new of 2-mercaptobenzimidazole salts evaluated against two pathogenic strains (E. coli and S. aureus) are presented in (Figure 1) (inhibition zones in the Agarwell diffusion assay). The molecules $\mathbf{4 b}, \mathbf{3 b}$ and $\mathbf{3 d}$ are the most active against the tested strains. In fact, the salt 4b showed significant activity against $S$. aureus $(30 \pm 2.12 \mathrm{~mm})$ and $E$. coli $(19.66 \pm 1.29 \mathrm{~mm})$. The molecule $\mathbf{3 b}$ also shows an important zone of inhibition $(15.66 \pm 1.93 \mathrm{~mm}$ for $E$. coli and $25.33 \pm 4.03 \mathrm{~mm}$ for $S$. aureus). Compounds $3 \mathbf{d}, \mathbf{4 c}$ and 3a have some antibacterial activity against $S$. Aureus; while, the excepted molecule 3d proved some inhibition against $S$. aureus, two all other molecules were not active. From our preliminary results, it appears that these compounds have an effect against Gram positive-bacteria more than Gram-negative bacteria ${ }^{25,26}$. Generally, the Gramnegative bacteria are the most sensitive to antibacterial agents than the Gram positive-bacteria. This difference is explained by the extra lipopolysaccharides and protein cell wall of Gramnegative bacteria that provides a permeability barrier to the antibacterial agent. On the other hand, the sensitivity of Gram-positive bacteria is related to the single layer of their cell wall, while the double membrane of Gram-negative bacteria should make them less sensitive ${ }^{27}$.

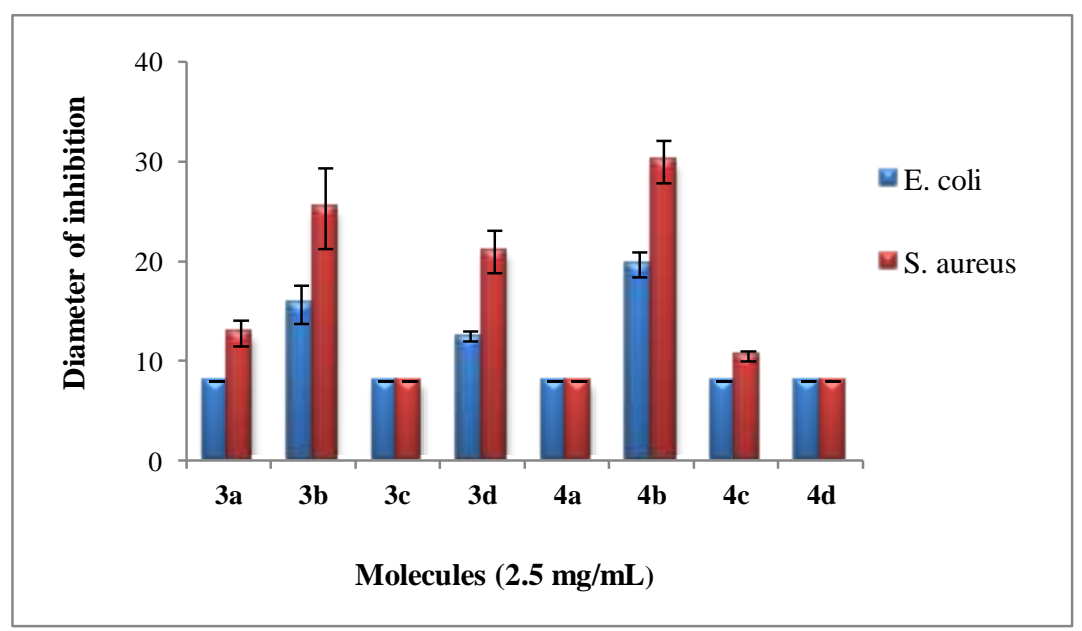

Figure 1. Antibacterial activity of 8 compounds at $2.5 \mathrm{mg} / \mathrm{mL}$ against E. coli and S. aureus. Bacterial density was about $10^{6} \mathrm{CFU} / \mathrm{mL}$, the diameter of well $(8 \mathrm{~mm})$ is included and the experiment was carried in triplicate.

The results are expressed as diameter around the well in $\mathrm{mm} \pm \mathrm{SD}$

\section{Determination of the minimum inhibitory concentration (MIC) and the minimum bactericidal concentration (MBC)}

The minimum inhibitory concentration (MIC) is defined as the minimum level of compound concentration that induces $90 \%$ reduction in the growth of microbial colonies. The MBC is defined as the minimum level of compound concentration that induces at least a $99.9 \%$ reduction in the growth of microbial colonies ${ }^{28}$. The MIC and MBC were determined by optical density and microdilution agar plate methods. Inoculums were prepared by inoculating medium LB with an overnight culture of 
S. aureus and E. coli incubating for three hours. 1 $\mathrm{mL}$ of aliquot of inoculums was added to $9 \mathrm{~mL}$ of medium of LB containing $0.15 \%$ of agar. Compounds were added to give the following final concentrations: $15,10,5,2.5,1.25$ and $0.75 \mathrm{mg} / \mathrm{mL}$. After $24 \mathrm{~h}$ of incubation at $37^{\circ} \mathrm{C}$, the optical density of the broths at $615 \mathrm{~nm}$ was measured with a UVvisible spectrophotometer (blank curve of absorbance at $620 \mathrm{~nm}$ ).
To evaluate the MIC and MBC, only compounds with inhibition halo with a higher diameter were tested (compounds $\mathbf{4 b}$ and $\mathbf{3 b}$ ). The optical density method using a reference curve of absorbance at 620 $\mathrm{nm}$ against the microbial concentration as $\mathrm{CFU} / \mathrm{mL}$, was constructed and used to test the effect of two molecules on the bacterial populations. The resulting points were fitted with a logarithmic tendency line of the form.

\section{Absorbance $=61.901(\mathrm{CFU} / \mathrm{mL})-\mathbf{7 . 8 7 6 9}$ for $S$. aureus}

\section{Absorbance $=5.9081 \mathrm{e}^{2.5973(\mathrm{CFU} / \mathrm{mL})}$ for $\boldsymbol{E}$. coli}

The optical densities of cultures of the inoculums in LB with different concentrations of compounds were determined and the equation above was used to infer the microbial populations. In that way, profiles of microbial counts vs. compounds concentration were obtained as indicated in the profile of $\mathbf{4 b}$ against $S$. aureus. The microbial populations for molecule-free tests were $1.5 \times 10^{6}$ $\mathrm{CFU} / \mathrm{mL}$ (Standard value). Therefore, the MIC was established through the microbial concentration of $1.5 \times 10^{5} \mathrm{CFU} / \mathrm{ml}$ as the same for the MBC one.

The profiles obtained $\mathbf{3 b}$ and $\mathbf{4 b}$ are shown in Figures 2,3 respectively. For the two tested compounds, the antibacterial effect is dosedependent. Indeed, at low concentrations, small changes in concentration produced large changes in the microbial growth. While, at high concentration, large changes in concentrations were needed to produce only minor changes in microbial growth. The values of MICs and MBCs are indicated in (Table 3). The compound $\mathbf{4 b}$ showed a MIC value at $6.5 \mathrm{mg} / \mathrm{mL}$ against $S$. aureus and $13 \mathrm{mg} / \mathrm{ml}$ against E. coli. While, the molecule $\mathbf{3 b}$ has a $\mathrm{MIC}=11.5$ $\mathrm{mg} / \mathrm{mL}$ against $S$. aureus and MIC $=13 \mathrm{mg} / \mathrm{mL}$. On the other hand, MBC was not reached at the highest concentration tested $(15 \mathrm{mg} / \mathrm{mL})$. This difference between MIC and MBC reveals that these two compounds at MIC values have a bacteriostatic action on the two bacterial strains. This action could be attributed to some specific interactions with bacterial targeting pathways, which induce a decrease in bacterial growth without bacterial lysis. Indeed, several studies showed numerous targeting pathways such as a disruption of potassium transport, protein coagulation and quorum sensing inhibition ${ }^{29-34}$. These results would be partially in accordance with the results of the Agar-well diffusion method in which the Compound $4 \mathbf{b}$ presented the largest inhibition halo than other molecules including the molecule $\mathbf{3 b}$. Several studies have shown the antibacterial activity of benzimidazole derivatives ${ }^{1,35}$. The effects of the latters have demonstrated an inhibition, at low concentration, against the same tested bacteria in our studies ( $E$. coli and $S$. aureus). The difference between these results is explained by the difference in functional molecular structure and methods used to reveal antibacterial inhibition.

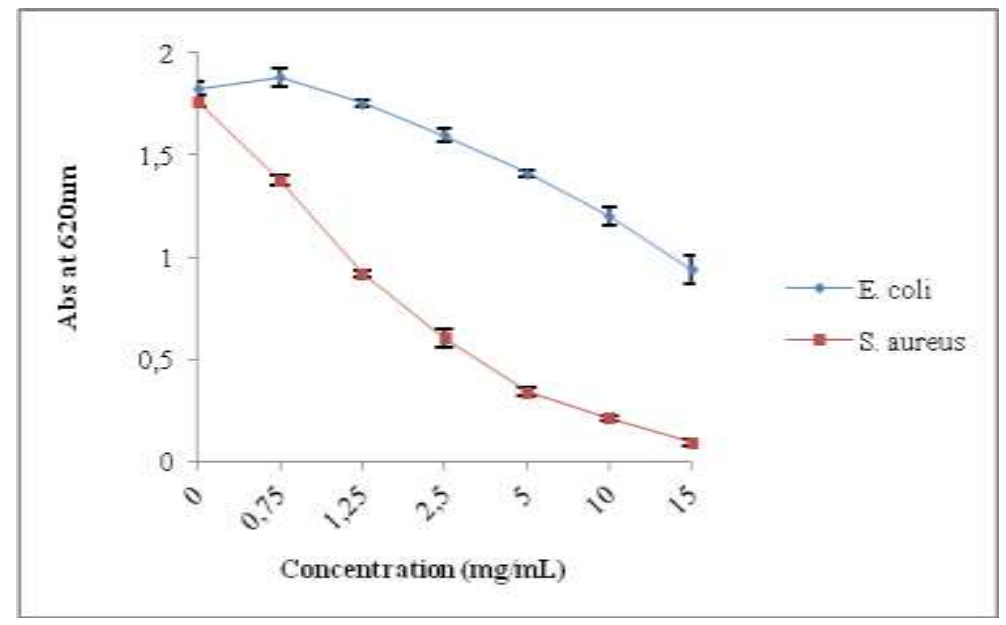

Figure 2. Absorbance at $620 \mathrm{~nm}$ of culture media incubated for $24 \mathrm{~h}$ with different concentrations of compound 3b against $E$. coli and $S$. Aureus 


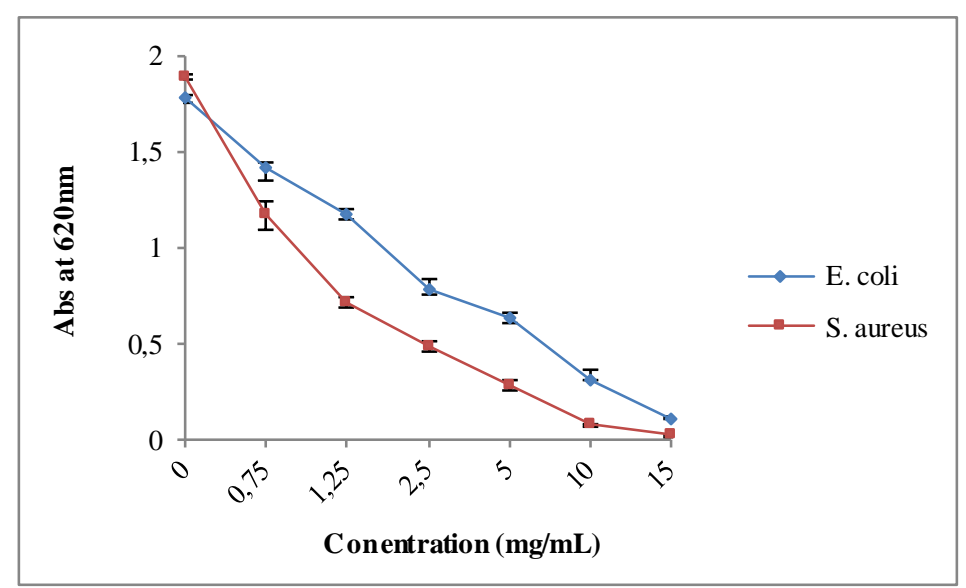

Figure 3. Absorbance at $620 \mathrm{~nm}$ of culture media incubated for $24 \mathrm{~h}$ with different concentrations of compound 4b against $E$. coli and $S$. aureus

Table 3. Values of MIC and MBC for $3 \mathrm{~b}$ and $4 \mathrm{~b}$ compounds as obtained by the optical density method

\begin{tabular}{|c|c|c|c|c|}
\hline \multirow{2}{*}{ Entry } & \multicolumn{2}{|c|}{ E. coli } & \multicolumn{2}{c|}{ S. aureus } \\
\cline { 2 - 5 } & MIC (mg/mL) & MBC $(\mathrm{mg} / \mathrm{mL})$ & $\mathrm{MIC}(\mathrm{mg} / \mathrm{mL})$ & $\mathrm{MBC}(\mathrm{mg} / \mathrm{mL})$ \\
\hline 3b & 13 & $>15$ & 11.5 & $>15$ \\
\hline 4b & 13 & $>15$ & 6.5 & $>15$ \\
\hline
\end{tabular}

\section{Kinetics of bacterial growth}

This study was conducted to evaluate the effect of compound $\mathbf{4 b}$ (showing the best antibacterial activity) on the kinetics of bacterial growth. Growth curves of bacteria in the presence of different concentrations of this compound against E. coli as showed in Figure 4 and against S. Aureus (Figure 5).

For E. coli, the growth is totally reduced at a concentration $2 \mathrm{MIC}=26 \mathrm{mg} / \mathrm{mL}$. While, at the MIC and $\mathrm{MIC} / 2=6.5 \mathrm{mg} / \mathrm{mL}$ concentrations the growth reduction starts after $4 \mathrm{hs}$ of incubation. These results revealed that a sub-inhibitor affects $\mathrm{E}$. coli in the initial phase of growth, while at the concentration of MIC and (MIC / 2), this compound affects only the bacterial growth during stationary stage. For S. Aureus, compound $\mathbf{4 b}$ affects the bacterial growth at MIC and 2 MIC (13 mg/mL) just after incubation (action during exponential stage). After 4hs of incubation, $S$. aureus has a normal growth. This result could be explained by a resistance mechanism against $S$. aureus after $4 \mathrm{~h}$ of incubation (time necessary for $S$. aureus to establish a resistance mechanism). On the other hand, several studies have showed that $S$. aureus can resist against numerous antibacterial agents by several mechanisms 36-38. However, the finding of our results suggesting that our molecules exert their action on specific targeting against this strain.

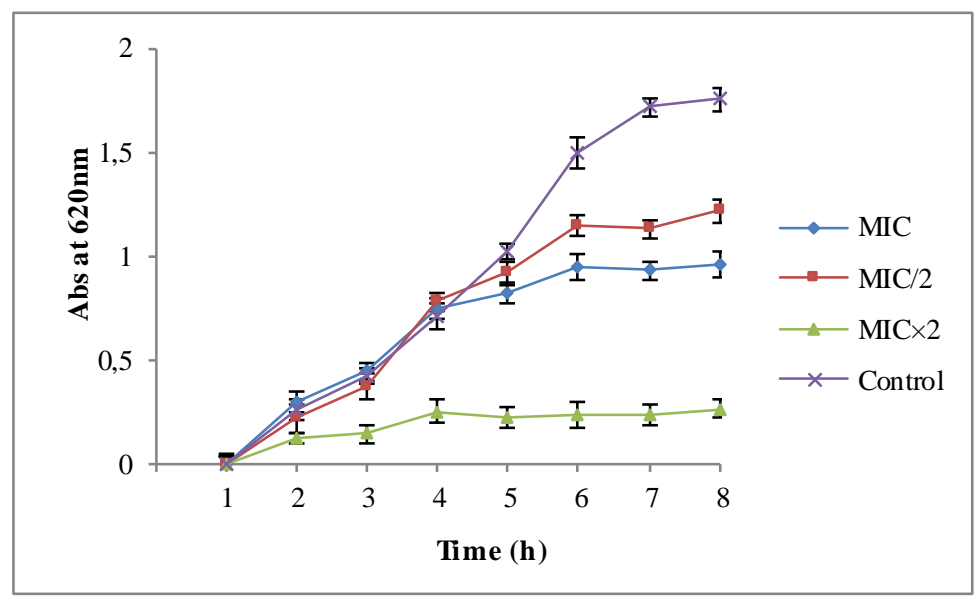

Figure 4. Kinetics of bacterial growth of $E$. coli of different concentrations of compound $\mathbf{4 b}$ (MIC, MIC/2, $\mathrm{MIC} \times 2)$ and control without molecule. Experiments were performed in duplicate. 


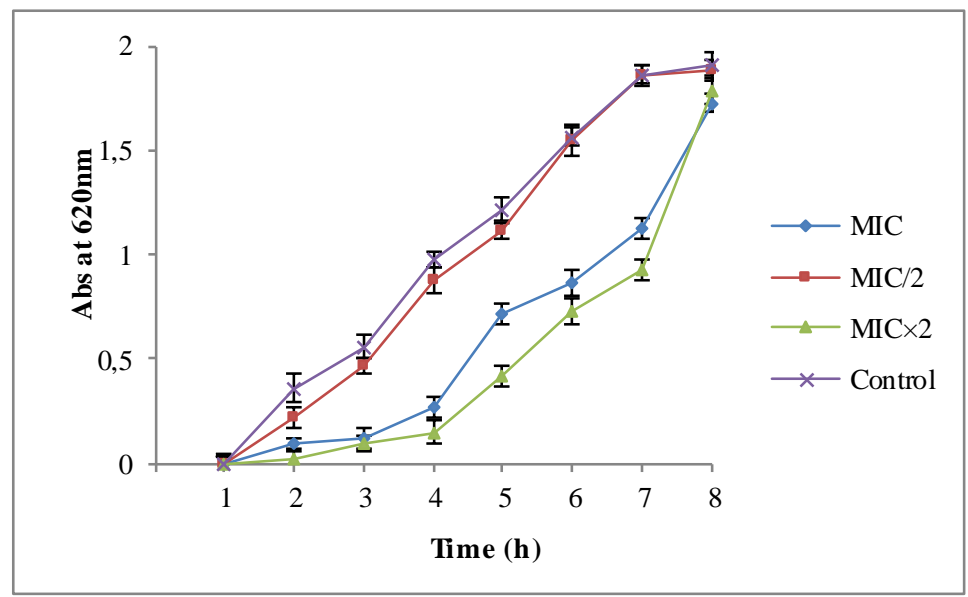

Figure 5. Kinetics of bacterial growth of $S$. aureus of different concentrations of compound $4 \mathbf{b}$ (MIC, MIC/2, $\mathrm{MIC} \times 2)$ and control without compound. Experiments were performed in duplicate.

\section{Antioxidant activity}

\section{DPPH radical scavenging capacity assay}

The results of the antioxidant activity tested by scavenging DPPH radical of cations 2-mercaptobenzimidazolium salts are shown in the
(Figure 6 and Figure 7). They are expressed in scavenging percentage of DPPH radical. All compounds have showed similar antioxidant effect with some non-significant variability.

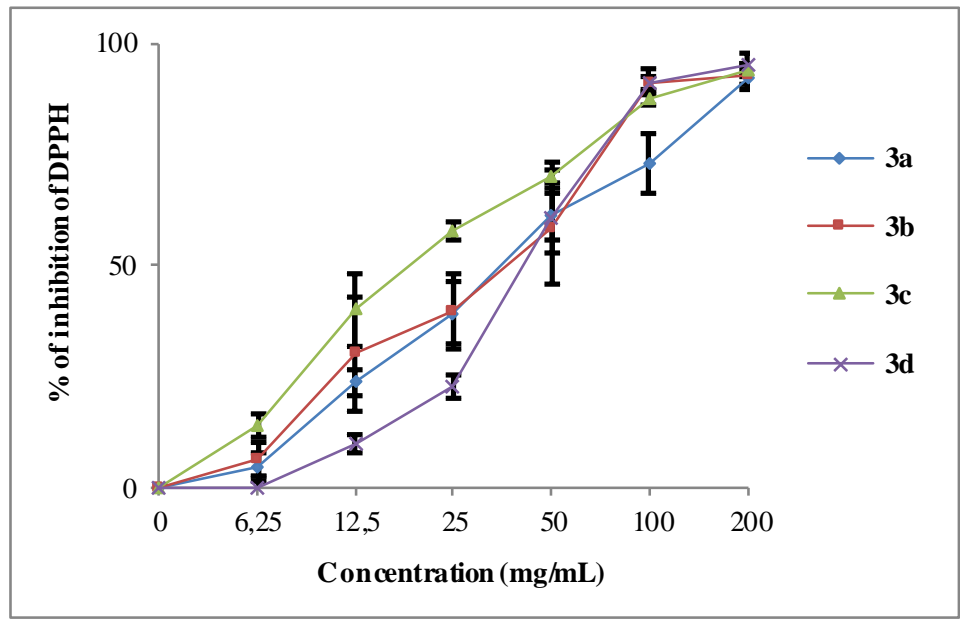

Figure 6. DPPH radical scavenging activities (\%) of compounds (3a, 3b, 3c, 3d) Values are means \pm standard deviation of three determinations.

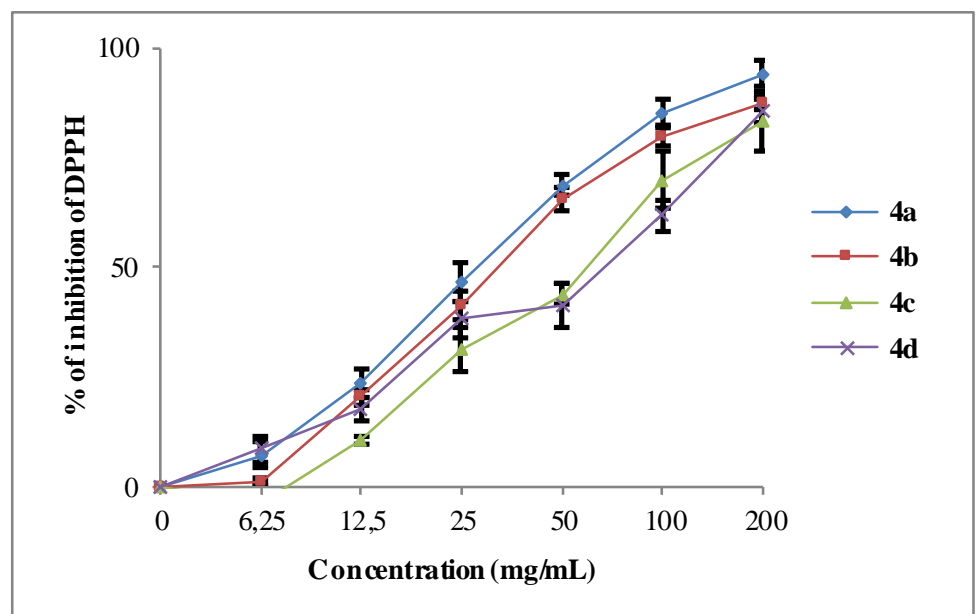

Figure 7. DPPH radical scavenging activities (\%) of compounds $(\mathbf{4 a}, \mathbf{4 b}, \mathbf{4} \mathbf{c}, \mathbf{4 d})$ Values are means \pm standard deviation of three determinations. 
Furthermore, for each compound, the ability to reduce the DPPH radical is concentration dependent. Therefore, the calculation of the effective concentration which reduces by $50 \%$ the initial concentration of DPPH $\left(\mathrm{IC}_{50}\right)$ is used to express the antiradical activity of studied molecules (Table 4). This capacity was determined from the graph of inhibition capacity (AA in \%) against compounds by using linear extrapolation. The value of the antioxidant capacity 50 is inversely proportional to the antiradical effectiveness of the compounds tested. It is clear that all compounds showed a lower capacity to reduce DPPH radical compared to the standard antioxidant (Trolox and ascorbic acid). The molecule 3c is the most active $\left(\mathrm{IC}_{50}=19.53 \mathrm{mg} / \mathrm{mL}\right)$. While, 4d was the most inactive molecule $\left(\mathrm{IC}_{50}=71.87 \mathrm{mg} / \mathrm{mL}\right)$. Some studies have revealed the antioxidant activity of benzimidazole derivatives ${ }^{1,3}$. The difference between results could be attributed to the molecular structure of synthesized compound and used method to provide antioxidant properties. The DPPH assay is a very common spectrophotometric method to determine the activity of any antioxidant. We have chosen DPPH radial due to the advantage of this method as the antiradical activity is measured at ambient temperature, and thus, the risk of the thermal degradation of the compound tested is eliminated ${ }^{39}$

Table 4. $\mathrm{IC}_{50}(\mathrm{mg} / \mathrm{mL})$ values of $\mathbf{3 a}, \mathbf{3 b}, \mathbf{3 c}, \mathbf{3 d}, \mathbf{4 a}$, $4 b, 4 c, 4 d$

\begin{tabular}{|c|c|}
\hline Entry & IC $_{\mathbf{5 0}}(\mathbf{m g} / \mathbf{m L})$ \\
\hline 3a & 37,5 \\
\hline 3b & 39,06 \\
\hline 3c & 19,53 \\
\hline 3d & 43,75 \\
\hline 4a & 29,68 \\
\hline 4b & 34,37 \\
\hline 4c & 62,5 \\
\hline 4d & 71,87 \\
\hline
\end{tabular}

\section{Conclusion}

In summary, we have developed an easy and efficient procedure for the synthesis of novel benzimidazolium. These compounds were prepared by condensation of 2-mercaptobenzimidazole with the various alkylating agents under the conditions of phase transfer catalysis, followed by a quaternization. There were screened for them invitro antibacterial activity against: Escherichia coli as Gram negative and Staphylococcus aureus as Gram positive. Results revealed that, compounds 1,3-Dinonyl-2-(nonylthio)-1H-benzimidazolium bromide $4 \mathbf{b}$ and 1-nonyl-2-(nonylthio)-1Hbenzimidazole $3 \mathbf{b}$ showed important antibacterial activity against two microorganisms especially Gram positive-bacteria. The kinetics of bacterial growth showed that compound $\mathbf{4 b}$ has a specific targeting against S. aureus and E. coli. Therefore, this molecule could be developed as a promising antibacterial agent. However, other studies regarding its mechanisms of action are needed, especially focusing on intracellular targeting pathways that leading to the bacterial cell death.

The radical scavenging ability of compounds 3a-d and 4a-d was tested by DPPH assay method. Higher the percentage inhibition for lower concentration is considered to be more antioxidant. It was found that synthesized compounds possess moderate antioxidant activity. These results demonstrated that molecules are not capable to give free electron to reduce the DPPH free radical. However, other studies on antioxidant activities of our molecules need investigation by other antioxidant assays such as Ferric reduction assay, APTS assay and FRAP to compare results.

\section{Acknowledgments}

***This work is dedicated to the memory of our Great Professor Rachid ZNIBER who passed away on December $27^{\text {th }} 2016$.

The authors thank the Unit of Support for Technical and Scientific Research (CNRST) and the University Mohammed V, Rabat, Morocco.

\section{Experimental}

Reagents were purchased from commercial sources and used as received without purification. Solvents were dried by standard procedures. ${ }^{1} \mathrm{H}$ NMR spectra were recorded in $\mathrm{CDCl}_{3}$ on a Bruker 300 spectrometer $(300 \mathrm{MHz})$ and ${ }^{13} \mathrm{C}$ NMR spectra were recorded in $\mathrm{CDCl}_{3}$ on a Bruker 300 spectrometer $(75 \mathrm{MHz})$. Chemical shift values were quoted in part per million and the coupling constants (J) in Hertz. Chemical shift multiplicities were reported as s, singlet; d, doublet; t, triplet; q, quartet; $\mathrm{m}$, multiplet....

\section{Typical Procedure for Synthesis of 3a-3d}

To a solution of $\left(133.10^{-4} \mathrm{~mol}\right)$ of 2-mercaptobenzimidazole and $80 \mathrm{ml}$ of N,N-dimethylformamide was added (26.6. mmol) of potassium carbonate, $(1.33 \mathrm{mmol})$ of tetra-n-butylammonium bromide and (39.9 mmol) of 1-bromodecane.

The reaction mixture was stirred at room temperature for 24 hours. After filtration, the solvent was removed under reduced pressure and the residue is taken up in dichloromethane, filtered and the solvent was evaporated under reduced pressure.

1-octyl-2-(octylthio)-1H-benzimidazole

(3a).

Yield: $88 \%$, pale yellow liquid,

${ }^{1} \mathrm{H}$ NMR spectrum $\left(300 \mathrm{MHz}, \mathrm{CDCl}_{3}\right), \delta, \operatorname{ppm}(J$, $\mathrm{Hz})$ : $0.86\left(\mathrm{~m}, 6 \mathrm{H}, \mathrm{CH}_{3}\right) ; 1.25-1.81\left(\mathrm{~m}, 24 \mathrm{H}, \mathrm{CH}_{2}\right)$; $3.44\left(\mathrm{t}, 2 \mathrm{H}, \mathrm{SCH}_{2}, J=14.7\right) ; 4.06\left(\mathrm{t}, 2 \mathrm{H}, \mathrm{NCH}_{2}, J=\right.$
14.7);
7.18-7.73
$(4 \mathrm{H}$,
$\mathrm{m}$,
$\mathrm{H}$ Ar). 
${ }^{13} \mathrm{C}$ NMR spectrum $\left(75 \mathrm{MHz}, \mathrm{CDCl}_{3}\right), \delta, \operatorname{ppm}(J$, $\mathrm{Hz}): 14.1\left(\mathrm{CH}_{3}\right) ; 22.6-31.8\left(\mathrm{CH}_{2}\right) ; 32.8\left(\mathrm{SCH}_{2}\right) ; 44.3$ $\left(\mathrm{NCH}_{2}\right) ; 108.8-142.4(\mathrm{C} \mathrm{Ar}) ; 152.1(\mathrm{C}=\mathrm{N})$.

Mass spectrum $[\mathrm{MH}]^{+} \mathrm{m} / \mathrm{z}=375$.

1-nonyl-2-(nonylthio)-1H-benzimidazole

(3b).

Yield: $91 \%$, pale yellow liquid,

${ }^{1} \mathrm{H}$ NMR spectrum $\left(300 \mathrm{MHz}, \mathrm{CDCl}_{3}\right), \delta, \mathrm{ppm}$ $(J, \mathrm{~Hz}): 0.97\left(6 \mathrm{H}, \mathrm{m}, \mathrm{CH}_{3}\right) ; 1.20-1.76(28 \mathrm{H}, \mathrm{m}$, $\left.\mathrm{CH}_{2}\right) ; 3.42\left(\mathrm{t}, 2 \mathrm{H}, \mathrm{SCH}_{2}, J=14.7\right) ; 4.05(\mathrm{t}, 2 \mathrm{H}$, $\left.\mathrm{NCH}_{2}, J=14.7\right) ; 7.16-7.70$ (4H , m, H Ar).

${ }^{13} \mathrm{C}$ NMR spectrum $\left(75 \mathrm{MHz}, \mathrm{CDCl}_{3}\right), \delta$, ppm $(J, \mathrm{~Hz}): 14.1\left(\mathrm{CH}_{3}\right) ; 22.6-31.8\left(\mathrm{CH}_{2}\right) ; 32.9\left(\mathrm{SCH}_{2}\right)$; $44.4\left(\mathrm{NCH}_{2}\right) ; 108.9-141.7(\mathrm{C} \mathrm{Ar}) ; 152.0(\mathrm{C}=\mathrm{N})$.

Mass spectrum $[\mathrm{MH}]^{+} \mathrm{m} / \mathrm{z}=403$.

1-decyl-2-(decylthio)-1H-benzimidazole

(3c).

Yield: $93 \%$, pale yellow liquid,

${ }^{1} \mathrm{H}$ NMR spectrum $\left(300 \mathrm{MHz}, \mathrm{CDCl}_{3}\right), \delta, \mathrm{ppm}$ $(J, \mathrm{~Hz}): 0.86\left(6 \mathrm{H}, \mathrm{m}, \mathrm{CH}_{3}\right) ; 1.24-1.84(32 \mathrm{H}, \mathrm{m}$, $\left.\mathrm{CH}_{2}\right) ; 3.52\left(\mathrm{t}, 2 \mathrm{H}, \mathrm{SCH}_{2}, J=14.7\right) ; 4.09(\mathrm{t}, 2 \mathrm{H}$, $\left.\mathrm{NCH}_{2}, J=14.7\right) ; 7.24-7.80$ (4H, m, H Ar).

${ }^{13} \mathrm{C}$ NMR spectrum $\left(75 \mathrm{MHz}, \mathrm{CDCl}_{3}\right), \delta, \mathrm{ppm}$ $(J, \mathrm{~Hz}): 14.1\left(\mathrm{CH}_{3}\right) ; 22.7-31.9\left(\mathrm{CH}_{2}\right) ; 33.1\left(\mathrm{SCH}_{2}\right)$; $44.6\left(\mathrm{NCH}_{2}\right) ; 109.1-135.1(\mathrm{C} \mathrm{Ar}) ; 151.9(\mathrm{C}=\mathrm{N})$.

Mass spectrum $[\mathrm{MH}]^{++} \mathrm{m} / \mathrm{z}=431$.

Anal. Calc for $\mathrm{C}_{27} \mathrm{H}_{46} \mathrm{~N}_{2} \mathrm{~S}$ C, 75,34\%, H, 10,69\%, N, 6,51\%, S, 7,44\% Found: C, 74,49\%, H, 10,64\%, $\mathrm{N}, 6,24 \%, \mathrm{~S}, 7,03 \%$.

1-dodecyl-2-(dodecylthio)-1H-benzimidazole (3d). Yield: 93\%, pale yellow liquid,

${ }^{1} \mathrm{H}$ NMR spectrum $\left(300 \mathrm{MHz}, \mathrm{CDCl}_{3}\right), \delta, \mathrm{ppm}$ $(J, \mathrm{~Hz}): 0.84\left(6 \mathrm{H}, \mathrm{m}, \mathrm{CH}_{3}\right) ; 1.21-1.81(40 \mathrm{H}, \mathrm{m}$, $\left.\mathrm{CH}_{2}\right) ; 3.50\left(\mathrm{t}, 2 \mathrm{H}, \mathrm{SCH}_{2}, J=14.4\right) ; 4.08(\mathrm{t}, 2 \mathrm{H}$, $\left.\mathrm{NCH}_{2}, J=14.7\right)$; 7.22-7.77 (4H, m, H Ar).

${ }^{13} \mathrm{C}$ NMR spectrum $\left(75 \mathrm{MHz}, \mathrm{CDCl}_{3}\right), \delta, \mathrm{ppm}$ $(J, \mathrm{~Hz}): 13.9\left(\mathrm{CH}_{3}\right) ; 22.7-34.1\left(\mathrm{CH}_{2}\right) ; 36.5\left(\mathrm{SCH}_{2}\right)$; $44.6\left(\mathrm{NCH}_{2}\right)$; 109.1-135.1 (C Ar); $151.9(\mathrm{C}=\mathrm{N})$.

Mass spectrum $[\mathrm{MH}]^{++} \mathrm{m} / \mathrm{z}=487$.

Anal. Calc for $\mathrm{C}_{31} \mathrm{H}_{54} \mathrm{~N}_{2} \mathrm{~S}$ C, 76,54\%, H, $11,11 \%$, N, 5,76\%, S, 6,59\% Found: C, 75,19\%, H, 10,86\%, N, $5,53 \%, \mathrm{~S}, 6,39 \%$.

\section{General Procedure for Synthesis of 4a-4d}

To a solution of $\left(26.10^{-4} \mathrm{~mol}\right)$ of 1-alkanyl-2(alkanylthio)-1H-benzimidazole and $40 \mathrm{ml}$ of acetonitrile was added $\left(53.10^{-4} \mathrm{~mol}\right)$ of 1-bromoalcane.

The reaction mixture was refluxed for 72 hours. After evaporating, the solvent was removed under reduced pressure. The oil obtained is chromatographed on silica gel column (eluent: hexane).

\section{1,3-Dioctyl-2-(octylthio)-1H-benzimidazolium} bromide (4a). Yield: $88 \%$, pale yellow liquid, ${ }^{1} \mathrm{H}$ NMR spectrum $\left(300 \mathrm{MHz}, \mathrm{CDCl}_{3}\right), \delta$, ppm $(J, \mathrm{~Hz}): 0.85\left(6 \mathrm{H}, \mathrm{m}, \mathrm{CH}_{3}\right) ; 1.24-1.86(36 \mathrm{H}, \mathrm{m}$, $\left.\mathrm{CH}_{2}\right) ; 3.38\left(\mathrm{t}, 2 \mathrm{H}, \mathrm{SCH}_{2}, J=13.8\right) ; 4.29(\mathrm{t}, 2 \mathrm{H}$, $\left.\mathrm{NCH}_{2}, J=15.3\right)$; 7.18-7.26 (4H, m, H Ar).
${ }^{13} \mathrm{C}$ NMR spectrum $\left(75 \mathrm{MHz}, \mathrm{CDCl}_{3}\right), \delta, \mathrm{ppm}$ $(J, \mathrm{~Hz})$ : $14.1\left(\mathrm{CH}_{3}\right) ; 22.6-32.9\left(\mathrm{CH}_{2}\right) ; 34.1\left(\mathrm{SCH}_{2}\right)$; $44.8\left(\mathrm{NCH}_{2}\right)$; 109.1-132.1 (C Ar); $168.9(\mathrm{C}=\mathrm{N})$. Electrospray ionization mass spectrometry (ESI-MS) $[\mathrm{M}]^{+} \mathrm{m} / \mathrm{z}=487$.

\section{1,3-Dinonyl-2-(nonylthio)-1H-benzimidazolium} bromide (4b). Yield: $80 \%$, pale yellow liquid, ${ }^{1} \mathrm{H}$ NMR spectrum $\left(300 \mathrm{MHz}, \mathrm{CDCl}_{3}\right), \delta$, ppm $(J, \mathrm{~Hz}): 0.85\left(6 \mathrm{H}, \mathrm{m}, \mathrm{CH}_{3}\right) ; 1.24-1.86(36 \mathrm{H}, \mathrm{m}$, $\left.\mathrm{CH}_{2}\right) ; 3.38\left(\mathrm{t}, 2 \mathrm{H}, \mathrm{SCH}_{2}, J=13.8\right) ; 4.29(\mathrm{t}, 2 \mathrm{H}$, $\left.\mathrm{NCH}_{2}, J=15.0\right)$; 7.17-7.26 (4H, m, H Ar).

${ }^{13} \mathrm{C}$ NMR spectrum $\left(75 \mathrm{MHz}, \mathrm{CDCl}_{3}\right), \delta, \mathrm{ppm}$ $(J, \mathrm{~Hz})$ : $14.1\left(\mathrm{CH}_{3}\right) ; 22.6-32.9\left(\mathrm{CH}_{2}\right) ; 34.0\left(\mathrm{SCH}_{2}\right)$; $44.8\left(\mathrm{NCH}_{2}\right)$; 109.0-132.1 (C Ar); $169.0(\mathrm{C}=\mathrm{N})$.

Electrospray ionization mass spectrometry (ESI-MS) $[\mathrm{M}]^{+} \mathrm{m} / \mathrm{z}=529$.

\section{1,3-Didecyl-2-(decylthio)-1H-benzimidazolium} bromide (4c). Yield: $83 \%$, pale yellow liquid, ${ }^{1} \mathrm{H}$ NMR spectrum $\left(300 \mathrm{MHz}, \mathrm{CDCl}_{3}\right), \delta$, ppm $(J, \mathrm{~Hz}): 0.84\left(6 \mathrm{H}, \mathrm{m}, \mathrm{CH}_{3}\right) ; 1.22-1.84(36 \mathrm{H}, \mathrm{m}$, $\left.\mathrm{CH}_{2}\right) ; 3.36\left(\mathrm{t}, 2 \mathrm{H}, \mathrm{SCH}_{2}, J=13.8\right) ; 4.27(\mathrm{t}, 2 \mathrm{H}$, $\left.\mathrm{NCH}_{2}, J=15.3\right)$; 7.16-7.40 (4H, m, H Ar).

${ }^{13} \mathrm{C}$ NMR spectrum $\left(75 \mathrm{MHz}, \mathrm{CDCl}_{3}\right), \delta$, ppm $(J, \mathrm{~Hz}): 14.1\left(\mathrm{CH}_{3}\right) ; 22.7-32.8\left(\mathrm{CH}_{2}\right) ; 33.9\left(\mathrm{SCH}_{2}\right)$; $44.8\left(\mathrm{NCH}_{2}\right)$; 108.9-132.1 ( $\left.\mathrm{C} \mathrm{Ar}\right) ; 169.1(\mathrm{C}=\mathrm{N})$. Electrospray ionization mass spectrometry (ESI-MS) $[\mathrm{M}]^{+} \mathrm{m} / \mathrm{z}=571$.

\section{1,3-Didodecyl-2-(dodecylthio)-1H-}

benzimidazolium bromide (4d). Yield: $78 \%$, pale yellow liquid,

${ }^{1} \mathrm{H}$ NMR spectrum $\left(300 \mathrm{MHz}, \mathrm{CDCl}_{3}\right), \delta, \mathrm{ppm}$ $(\mathrm{J}, \mathrm{Hz})$ : $0.87\left(6 \mathrm{H}, \mathrm{m}, \mathrm{CH}_{3}\right) ; 1.25 .1 .86\left(36 \mathrm{H}, \mathrm{m}, \mathrm{CH}_{2}\right)$; $3.38\left(\mathrm{t}, 2 \mathrm{H}, \mathrm{SCH}_{2}, J=13.8\right) ; 4.29\left(\mathrm{t}, 2 \mathrm{H}, \mathrm{NCH}_{2}\right.$, $J=15.0)$; 7.17-7.26 (4H, m, H Ar).

${ }^{13} \mathrm{C}$ NMR spectrum $\left(75 \mathrm{MHz}, \mathrm{CDCl}_{3}\right), \delta, \mathrm{ppm}$ (J, Hz): $14.1\left(\mathrm{CH}_{3}\right)$; 22.7-32.9 $\left(\mathrm{CH}_{2}\right) ; 33.8\left(\mathrm{SCH}_{2}\right)$; $44.9\left(\mathrm{NCH}_{2}\right)$; $108.9-132.1(\mathrm{C} \mathrm{Ar}) ; 169.1(\mathrm{C}=\mathrm{N})$.

Electrospray ionization mass spectrometry (ESI-MS) $[\mathrm{M}]^{+} \mathrm{m} / \mathrm{z}=655$.

\section{Antibacterial activity}

In order to evaluate the antibacterial activity of the synthesized compounds, two bacteria strains were used: Escherichia coli K12 (Laboratory of Food Microbiology, UCL, Belgium: MBLA) and Staphylococcus aureus CECT 976 (Spanish Type Culture Collection: CECT). Strains are maintained on an inclined agar medium at $4^{\circ} \mathrm{C}$. Before use, the bacteria were revived by two subcultures in an appropriate culture medium: Luria-Bertoni (LB) broth at $37^{\circ} \mathrm{C}$ for 18 to 24 hours. For the test, final inoculums concentrations of $10^{6} \mathrm{CFU} / \mathrm{ml}$ bacteria were used.

A basal layer was prepared by Muller-Hinton agar. The agar plates were then solidified and sterile $8 \mathrm{~mm}$ diameter cylinders were deposited. 
Six $\mathrm{ml}$ of LB medium in superfusion containing $0.8 \%$ agar were inoculated by a fresh culture of bacterial strain indicator (a final concentration was $10^{6} \mathrm{CFU} / \mathrm{mL}$ ). After solidification, the wells were filled with $50 \mu \mathrm{L}$ of diluted molecules at 2.5 $\mathrm{mg} / \mathrm{mL}^{25}$. After incubation at appropriate temperature for $24 \mathrm{~h}$, all plates were examined for any zone of growth inhibition, and the diameter of these zones were measured in millimetres.

\section{Minimal inhibitory concentration (MIC) and the minimal bactericidal concentration (MBC)}

The minimum inhibitory concentration (MIC) is defined as the minimum level of compound concentration that induces $90 \%$ reduction in the growth of microbial colonies. The $\mathrm{MBC}$ is defined as the minimum level of compound concentration that induces at least a $99.9 \%$ reduction in the growth of microbial colonies 28. The MIC and MBC were determined by optical density and microdilution agar plate methods. Inoculums were prepared by inoculating medium LB with an overnight culture of $S$. aureus and E. coli incubating for three hours. 1 $\mathrm{mL}$ of aliquot of inoculums was added to $9 \mathrm{~mL}$ of medium of LB containing $0.15 \%$ of agar. Compounds were added to give the following final concentrations: $15,10,5,2.5,1.25$ and $0.75 \mathrm{mg} / \mathrm{mL}$. After $24 \mathrm{~h}$ of incubation at $37^{\circ} \mathrm{C}$, the optical density of the broths at $615 \mathrm{~nm}$ was measured with a UVvisible spectrophotometer (blank curve of absorbance at $620 \mathrm{~nm}$ ).

\section{Kinetics of bacterial growth}

Inoculums were prepared by inoculating medium LB with an overnight culture of $S$. aureus and E. coli incubating for three hours. $1 \mathrm{~mL}$ of aliquot of inoculums was added to $9 \mathrm{ml}$ of medium of LB containing $0.15 \%$ of agar. The compounds $\mathbf{4 b}$ and $\mathbf{3 b}$ were added to each tube to achieve final concentrations of compound of 2 MIC, MIC and $\mathrm{MIC} / 2$. The bacterial culture used without compounds was considered as negative control. The tubes were incubated at $37^{\circ} \mathrm{C}$. The optical density at a wavelength of $620 \mathrm{~nm}$ was measured every hour during the period of growth in order to monitor the bacterial growth. Experiments were performed in triplicate.

\section{Antioxidant activity: DPPH radical scavenging capacity assay}

Aliquots $(0.2 \mathrm{~mL})$ of various concentrations $(6.25-200 \mathrm{mg} / \mathrm{mL})$ of the synthetic compounds samples were added to $1.8 \mathrm{~mL}$ of a $0.004 \%$ methanolic solution of DPPH. After an incubation period of $30 \mathrm{~min}$ in darkness at room temperature, the absorbance was recorded against a blank at 517 $\mathrm{nm}$ with a spectrophotometer. Absorption of a blank sample containing the same amount of methanol and DPPH solution used as control. DPPH free radical- scavenging activity in percentage (\%) was calculated using the following formula:

$$
\% \text { Inhibition }=\left[\left(\mathbf{A}_{\text {blanc }}-\mathbf{A}_{\text {sample }}\right) / \mathbf{A}_{\text {blanc }}\right] \times \mathbf{1 0 0}
$$

Where $A_{\text {blanc }}$ is the absorbance of the control reaction (containing all reagents except the test compound) and $\mathrm{A}_{\text {sample }}$ is the absorbance of the test compound. Compounds concentration providing $50 \%$ inhibition $\left(\mathrm{IC}_{50}\right)$ was calculated from the graph plotted of inhibition percentage.

\section{References}

1- A. Ts. Mavrova, D. Yancheva, N. Anastassova, K. Anichina, J. Zvezdanovic, A. Djordjevic, D. Markovic, A. Smelcerovic, Synthesis, electronic properties, antioxidant and antibacterial activity of some new benzimidazoles, Bioorganic \& Medicinal Chemistry, 2015, 23, 19, 6317-6326.

2- M. Andrzejewska, L. Yepez-Mulia, A. Tapia, R. Cedillo-Rivera, A. E. Laudy, B. J. Staro'sciak, Z. Kazimierczuk, Synthesis, and antiprotozoal and antibacterial activities of $S$ substituted 4,6-dibromo- and 4,6-dichloro-2mercaptobenzimidazoles, European Journal of Pharmaceutical Sciences, 2004, 21, 323-329.

3- K. K. Sumayya, V. K. Kamalabhai Amma, G. Babu, C. R Biju, Synthesis, Characterization and Antioxidant studies of 2-Benzylthio benzimidazole derivatives, Int. J. Chem. Pharm. Sci, 2013, 1, 3, 193-198.

4- K. Anandarajagopal, R. N. Tiwari, K.G. Bothara, J. A. Jeba Sunilson, C. Dineshkumar, P. Promwichit, 2Mercaptobenzimidazole Derivatives: Synthesis and Anticonvulsant Activity, Advances in Applied Science Research, 2010, 1, 2, 132-138.

5- M. V. De Almeida, S. H. Cardoso, J. V. De Assis, M. V. N. De Souza, Synthesis of 2-mercapto-benzothiazole and 2-mercaptobenzimidazole derivatives condensed with carbohydrates as a potential antimicrobial agents, J. Sulfur,Chem., 2007, 28, 17-22.

6- $\quad$ M. Mor, F. Bordi, C. Silva, S. Rivara, V. Zuliani, F. Vacondio, M. Rivara,

E. Barocelli, S. Bertoni, V. Ballabeni, F. Magnanini, M. Impicciatore, P. Vincenzo Plazzi, Synthesis, biological activity, QSAR and QSPR study of 2-aminobenzimidazole derivatives as potent $\mathrm{H} 3$-antagonists, Bioory, Med. Chem., 2004, 12, 4, 663-674.

7- E. V. Bakhareva, M.G. Voronkov, M. S. Sorokin, V. A. Lopyrev, S. B. Seredenin, G. M Gaidarov, Synthesis and neurotropic properties of 2-(carboxymethylthio) derivatives of benzimidazole, benzothiazole and their ammonium salts, Pharm. Chem. J., 1996, 30, 2, 89-91. 
8- $\quad$ A.Anand, M. V. Kulkarni, S. D. Joshi, S. R. Dixit, One pot Click chemistry: A three component reaction for the synthesis of 2mercaptobenzimidazole linked coumarinyl triazoles as anti-tubercular agents, Bioorganic \& Medicinal Chemistry Letters, 2016, 26, 4709-4713.

9- K. Anandarajagopal, R. N. Tiwari, N. Venkateshan, G. V. Pooshan, P. Promwichit, Synthesis and characterization of 2mercaptobenzimidazole derivatives as potential analgesic agents, J. Chem. Pharm. Res., 2010, 2, 3, 230-236.

10- T. L. Rebstock, C. D. Ball, C. L. Hamner, H. M. Sell, Inhibition of Plant Growth by 2Mercapto-benzimidazole Analogs, Plant physiology, 1955, 30, 4, 382-384.

11- B. Zhong, Z. Jia, Y. Luo, B. Guo, D. Jia, Preparation of halloysite nanotubes supported 2-mercaptobenzimidazole and its application in natural rubber, Composites: Part A, 2015, 73, 63-71.

12- L. El Ouasif, I. Merimi, H. Zarrok, M. El ghoul, R. Achour, M. Guenbour, H. Oudda, F. El-Hajjaji, B. Hammouti, Synthesis and inhibition study of carbon steel corrosion in hydrochloric acid of a new surfactant derived from 2-mercaptobenzimidazole, J. Mater. Environ. Sci., 2016, 7, 8, 2718-2730.

13- M.Th. Makhlouf, S.A. El-Shatory, A. El-Said, The synergistic effect of halide ions and some selected thiols as a combined corrosion inhibitor for pickling of mild steel in sulphuric acid solution, Mater. Chem. Phys., 1996, 43, 1, 76-82.

14- S. A. M. Refaey, F. Taha, A. M. Abd El-Malak, Corrosion and Inhibition of 316L stainless steel in neutral medium by 2 -

Mercaptobenzimidazole, Int. J. Electrochem. Sci., 2006, 1, 80-91.

15- Wang, L., Evaluation of 2mercaptobenzimidazole as corrosion inhibitor for mild steel in phosphoric acid, Corros. Sci., 2001, 43, 12, 2281.

16- Lin Wang, J.-X. Pu, H.-C. Luo, Corrosion inhibition of zinc in phosphoric acid solution by 2-mercapto-benzimidazole, Corros. Sci., 2003, 45, 4, 677-683.

17- M. C. Costache, M. J. Heidecker, E. Manias, R. K. Gupta, C. A. Wilkie, Benzimidazolium surfactants for modification of clays for use with styrenic polymers, Polymer Degradation and Stability, 2007, 92, 10, 1753-1762.

18- M. El Achaby, H. Ennajih, F.Z. Arrakhiz, A. El Kadib, R. Bouhfid, E. Essassi, A. Qaiss, Modification of montmorillonite by novel geminal benzimidazolium surfactant and its use for the preparation of polymer organoclay nanocomposites, Composites: Part B, 2013, 51, 310-317.

19- G. Cai, J.Feng, J. Zhu, C. A. Wilkie, Polystyrene- and poly (methyl methacrylate)- organoclay nanocomposites using a one-chain benzimidazolium surfactant, Polymer Degradation and Stability, 2014, 99, 204-210.

20- S. Ramkumar, K.-G. Upul Wijayantha, D. Velayutham, S. Anandan, Synthesis of 1, 3-dihexyl-2-(phenylthio)-1Hbenzo[d]imidazol- 3-ium iodide-A new ionic liquid for dye sensitized solar cell applications, Journal of Molecular Liquids, 2014,193, 185-188.

21- N. N. Al-Mohammed, R. S. Duali Hussen, T. Hussein Ali, Y. Alias, Z. Abdullah, Tetrakisimidazolium and benzimidazolium ionic liquids: a new class of biodegradable surfactants, RSC Adv., 2015, 5, 21865-21876.

22- A. El Kadib, E. Essassi, R. Bouhfid, H. Ennajih, Préparation de nouveaux biocomposites chitosan-argile modifiée, $\mathrm{N}^{\circ}$ brevet MA34933 B1, 01.03, 2014.

23- A. K. Lal, M. D. Milton, Synthesis of new benzimidazolium salts with tunable emission intensities and their application as fluorescent probes for $\mathrm{Fe} 3+$ in pure aqueous media, Tetrahedron Letters, 2014, 55, 10, 1810-1814.

24- M. Bousmina, E. Essassi, R. Bouhfid, H. Ennajih, Surfactants pour la modification d'argile, méthode de synthèse et les nanocomposites produits, $\mathrm{N}^{\circ}$ brevet $\mathrm{WO}$ 2012/011793 A1, 26.01, 2012.

25- A. Bouyahya, J. Abrini, EO. Khay, S.Charfi, N. Boujida, A. EL Harsal, A. Talbaoui, A. ET-Touys, Y. Bakri, N. Dakka, In vitro Antibacterial Activity of Organic Extracts from North-West Moroccan Medicinal Plant Myrtus communis (L.)., Biotechnology Journal International, 2016 a , 16, 1-9.

26- A. Bouyahya, J. Abrini, A. El-Baabou, Y. Bakri, N. Dakka, Determination of phenol content and antibacterial activity of five medicinal plants ethanolic extracts from NorthWest of Morocco, J Plant Pathol Microbiol, 2016 c, 7, 107-111.

27- G.J. Kaur, D.S. Arora, Antibacterial and phytochemical screening of Anethum graveolens, Foeniculum vulgare and Trachysprmum ammi, BMC Complement Altern Med, 2009, 6, 9-30.

28- P. Skandamis, K. Koutsoumanis, K. Fasseas, G.J.E. Nychas, Inhibition of oregano essential oil and EDTA on E. coli O157: H7, Italian Journal of Food Science, 2001,13, 65-75.

29- S. Bouhdid, J. Abrini, M. Amensour, A. Zhiri, M. J. Espung, A. Manresa, Functional and ultrastructural changes in Pseudomonas aeruginosa and Staphylococcus aureus cells induced by Origanum compactum essential oil, Journal of Applied Microbiology, 2009, 106, 1558-1568.

S. Bouhdid, J. Abrini, M. Amensour, A. Zhiri, M. J. Espung, A. Manresa, Functional and ultrastructural changes in Pseudomonas aeruginosa and Staphylococcus aureus cells 
induced by Cinnamomum verum essential oil,Journal of Applied Microbiology, 2010, 109, 1139-1149.

30- H. Barakat, Composition, Antioxidant, Antibacterial Activities and Mode of Action of Clove (Syzygium aromaticum L.) Buds Essential Oil, Journal of Applied Science \& Technology, 2014, 4, 1934-1951.

31- B.D. Oliveira, A.C. Rodrigues, BMI Cardoso, A.L.C.C. Ramos, M.C. Bertoldi, J.G. Jason Guy Taylor, L.R. Luciana da Cunha, U.M. Pinto, Antioxidant, antimicrobial and antiquorum sensing activities of Rubusrosaefolius phenolic extract, Industrial Crops and Products, 2016, 84, 59-66.

32- K. Myszka, M.T. Schmidt, M. Majcher, W. Juzwa, M. Olkowicz, K. Czaczyk., Inhibition of quorum sensing-related biofilm of Pseudomonas fluorescens KM121 by Thymus vulgare essential oil and its major bioactive compounds., International Biodeterioration \& Biodegradation, 2016, 114, 252-259.

33- A. Luís, A. Duarte, J. Gominho, F. Domingues, A.P. Duarte, Chemical composition, antioxidant, antibacterial and anti-quorum sensing activities of Eucalyptus globulus and Eucalyptus radiata essential oils, Industrial Crops and Products, 2016, 79, 274-282.

34- K. Parikh, D. Joshi, Antibacterial and antifungal screening of newly synthesized benzimidazole-clubbed chalcone derivatives, Med. Chem. Res., 2013, 22, 3688-3697.

35- F.D. Lowy, Antimicrobial resistance: the example of Staphylococcus aureus, J. Clin. Invest., 2003, 111, 9, 1265-1273.

36- A. Pantosti, A. Sanchini, M. Moaco, Mechanisms of antibiotic resistance in Staphylococcus aureus, Future Microbiol., 2007, 2, 3, 323-340.

37- K. Hiramatsu, L. Cui, M. Kuroda, T. Ito, The emergence and evolution of methicillinresistant Staphylococcus aureus, Trends Microbiol., 2001, 9, 486-493.

38- V. Bondet, W. Brand-Williams, C. Berset, Kinetics and mechanisms of antioxidant activity using the DPPH free radical method, LWT-Food Sci. Technol, 1997, 30, 609-615. 